\title{
7. CRETACEOUS RADIOLARIANS FROM THE ONTONG JAVA PLATEAU, WESTERN PACIFIC, HOLES 803D AND 807C ${ }^{1}$
}

\author{
Kozo Takahashi ${ }^{2}$ and Hsin-Yi Ling ${ }^{3}$
}

\begin{abstract}
Among the five sites drilled during Ocean Drilling Program Leg 130, two deep holes (803D and 807C) penetrated Cretaceous sediments overlying the basaltic pillows, flows, and possibly basement rocks. Abundant, poorly preserved radiolarians with limited diversity were recovered from a few horizons within the sediments proximal to the basalt. At Site 803, three thin layers of radiolarites interbedded with claystone and clayey siltstone yielded radiolarian assemblages of late Albian age. At Site 807, several layers of radiolarian siltstones were recovered proximal to the basalt. Among them the most significant radiolarian assemblage is an Aptian fauna, located approximately $7 \mathrm{~m}$ above the basaltic flows. The Aptian radiolarian age for Site 807 is at least in accord with those suggested by planktonic foraminifer and paleomagnetic evidence. These Cretaceous radiolarians are the oldest assemblages recorded from the Ontong Java Plateau region.
\end{abstract}

\section{INTRODUCTION}

Major objectives of Ocean Drilling Program (ODP) Leg 130 included elucidation of the age of the Ontong Java Plateau and assessment of its relationship with the extensive "mid-Cretaceous" volcanic events of the Pacific (Kroenke, Berger, Janecek, et al., 1991). The biostratigraphy of sediments that directly overlie basement rocks is as crucial as the chronology of the basalt itself to the Ontong Java Plateau. Cretaceous sediments were encountered from two holes out of five sites during the 1990 drilling operation: Hole $803 \mathrm{D}\left(2^{\circ} 25.98^{\prime} \mathrm{N}\right.$, $160^{\circ} 32.46^{\prime} \mathrm{E}, 3412 \mathrm{~m}$ water depth) and Hole $807 \mathrm{C}\left(3^{\circ} 36.39^{\prime} \mathrm{N}\right.$, $156^{\circ} 37.48^{\prime} \mathrm{E}, 2805 \mathrm{~m}$ water depth) (Kroenke, Berger, Janecek, et al., 1991) (Fig. 1).

These holes encountered one of the oldest radiolarian-bearing sediments from the area and thus provide useful insight into the geology of the Pacific Cretaceous. Previously, the oldest stratigraphically useful radiolarian assemblages recognized in the vicinity of the area were late middle Eocene in age from Deep Sea Drilling Project (DSDP) Site 64 (Riedel and Sanfilippo, 1971). At DSDP Site 289, Ontong Java Plateau (Fig. 1), the oldest sediments were dated as late Aptian based on planktonic foraminifers (Tarduno et al., 1991). Unfortunately, however, at Site 289 only traces of poorly preserved radiolarians were found in the Cretaceous sediments (Andrews, Packham, et al., 1975, p. 254), and thus it was not possible to determine a Cretaceous radiolarian biostratigraphy. DSDP Site 586, also located on Ontong Java Plateau, only penetrated late Miocene sediments (Shipboard Scientific Party, 1986). Here we report on the Cretaceous fauna from Ontong Java Plateau, its composition, and relative abundance of taxa within the assemblages.

Site 803 is located on the northeastern margin of the Ontong Java Plateau, approximately $400 \mathrm{~km}$ northeast of DSDP Sites 289/586 (see Fig. 1). Based on calcareous nannofossils, Cretaceous sediments were identified in Sections 130-803D-68R-1 through -68R-3, 621.8-626.3 $\mathrm{m}$ below seafloor (mbsf). These sediments consist of claystone and clayey siltstone, with three layers of soft, dark yellowish brown (10 YR 4/4) radiolarites in Section 130-803D-68R-3.

Site 807 is on the northern margin of the Ontong Java Plateau, approximately $475 \mathrm{~km}$ northwest of DSDP Sites 289/586 (see Fig. 1). Sediments below Section 130-807C-54R-3, $13 \mathrm{~cm}$ (about $1193 \mathrm{mbsf}$ ),

\footnotetext{
'Berger, W.H., Kroenke, L.W., Mayer, L.A., et al., 1993. Proc. ODP, Sci. Results, 130: College Station, TX (Ocean Drilling Program).

${ }^{2}$ Department of Geology and Geophysics, Woods Hole Oceanographic Institution, Woods Hole, MA 02543, U.S.A.

${ }^{3}$ Department of Geology, Northern Illinois University, Dekalb, IL 60115, U.S.A.
}

are considered Cretaceous based on planktonic foraminifers, calcareous nannofossils, and radiolarians. Varying amounts of radiolarians were recovered from several isolated horizons: from Cores 130-807C$71 \mathrm{R}$ through $-74 \mathrm{R}$ within the Subunit IIIA claystone and siltstone (Kroenke, Berger, Janecek, et al., 1991). Radiolarians were also found in two limestone layers in Sections 130-807C-80R-1 and -82R-3 located between pillow basalts. Nevertheless, they are poorly preserved, rare, non-age-diagnostic spumellarians (or nassellarians; see later section). No radiolarian age for these limestones can be provided.

The Ontong Java Plateau was located in the middle latitude during the early Cretaceous. For instance, the reconstructed paleolatitude of Site 807 at $120 \mathrm{Ma}$ is $34^{\circ} \mathrm{S}$ (Tarduno et al., 1991).

\section{METHOD OF ANALYSIS}

For radiolarites, claystone, and siltstone, several cubic centimeters of sediments were placed in $40-\mathrm{ml}$ beakers containing 2 tsp of Calgon, followed by the addition of hot water and $5 \mathrm{ml}$ of $30 \%$ hydrogen peroxide. The samples were treated in an ultrasonic bath for about 3 min followed by wet sieving with a $63-\mu \mathrm{m}$ mesh screen. For limestone, several cubic centimeters of samples were ground in a mortar with a pestle to which hydrochloric acid was added in a beaker. This mixture was then treated by the same method as mentioned above. The standard radiolarian treatment, with $\mathrm{HCl}-\mathrm{H}_{2} \mathrm{O}_{2}$ typically used for submarine sediments, failed to yield clean radiolarian specimens of Cretaceous age because of the hard clay matrix interlocked with radiolarians. A portion of the retained fraction was then mounted on microslides with a $22 \times 50 \mathrm{~mm}$ cover glass using Canada balsam as a mounting medium. Radiolarians were examined and representative taxa were photographed with a Zeiss Photomicroscope. Selected specimens were also illustrated using a JOEL JSM-840 scanning electron microscope (SEM) after specimens were handpicked and coated with gold.

All microslides examined for this investigation will be permanently deposited at Woods Hole Oceanographic Institution, Woods Hole, Massachusetts, U.S.A.

\section{RADIOLARIAN OCCURRENCE AND STATE OF PRESERVATION}

The distribution of radiolarians and their relative abundance are shown in Table 1. These radiolarian skeletons are diagenetically altered significantly. The skeletons appear to be altered to quartz or zeolite; the void spaces in the interior of spumellarian cortical shells or conical nassellarian shells are filled with the same material as 
A

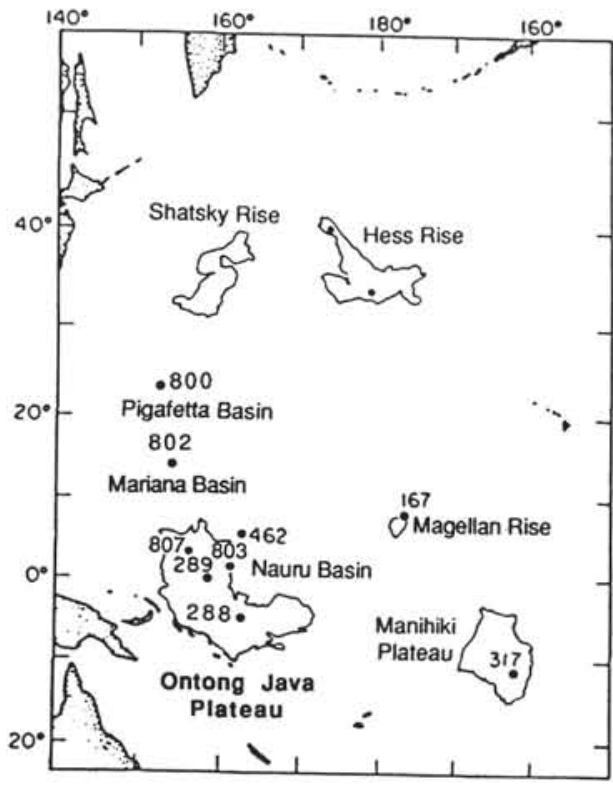

B

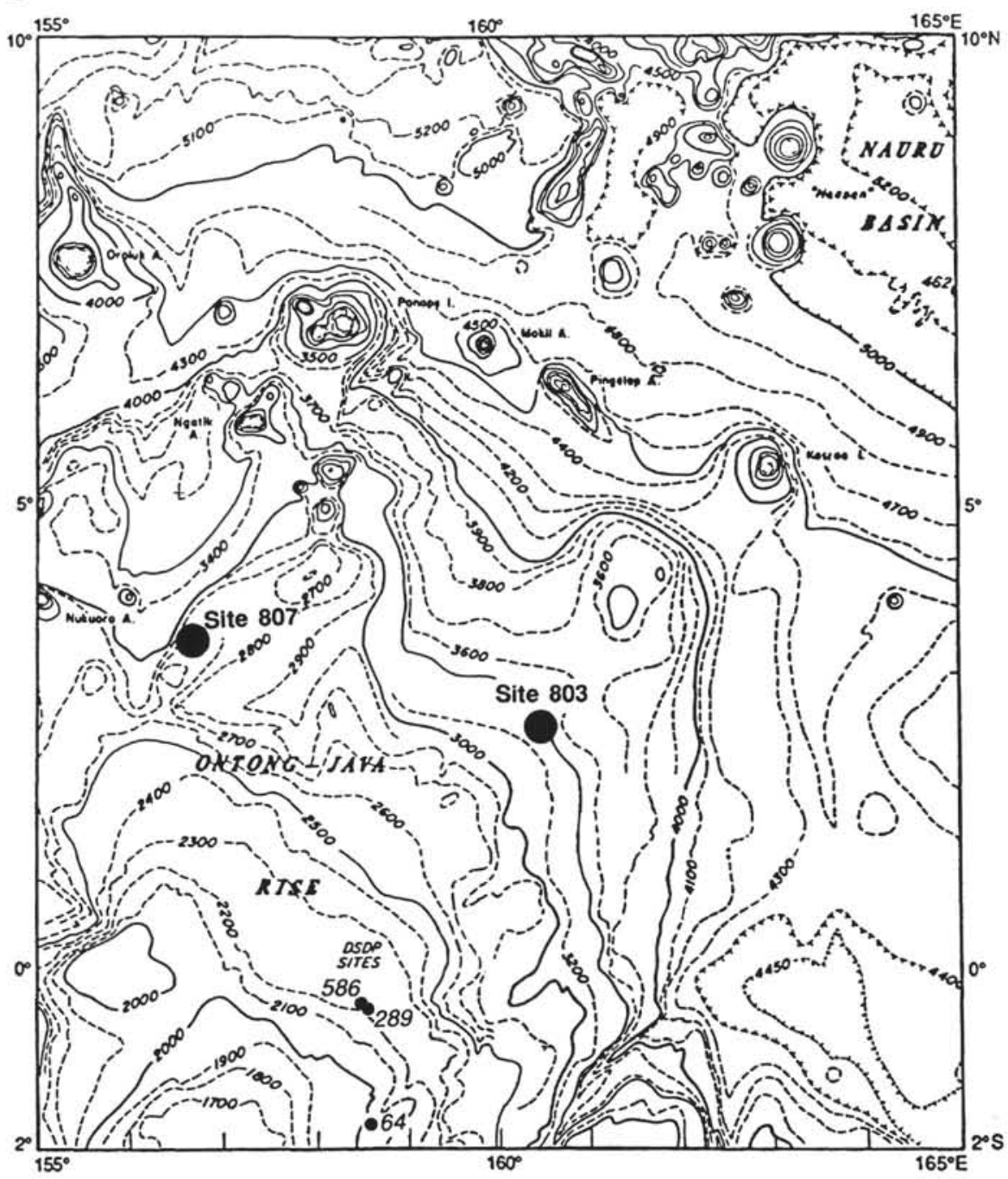

Figure 1. A. Location of the Ontong Java Plateau, Mid-Pacific Mountains, Manihiki Plateau, and Magellan Rise (4000-m contour), modified after Tarduno et al. (1991). Sites drilled in the region are also shown. B. Bathymetry of the Ontong Java Plateau region. Sites drilled during Leg 130 where Cretaceous radiolarians occur are illustrated by large solid circles, and sites drilled during previous DSDP cruises are shown by small filled circles. Contour intervals in meters.

composes the skeletons. Fortunately, some of the surface ornamentation and/or structure of these specimens is often well preserved (see plates) despite the diagenesis, permitting taxonomic identification for some key taxa. Nevertheless, even with SEM examination, many spumellarian and/or nassellarian taxa such as Holocryptocanium (see Dumitrica, 1970; Baumgartner, 1984) could not be identified to specific or generic levels because of the altered preservation state.

Because radiolarians in limestone are often replaced with carbonates, treatment with hydrochloric acid precluded the extraction of complete specimens. Nevertheless, radiolarian skeletal morphology was sometimes recognized as a form of mold, especially that made of clays and silts existing within the limestone matrix.

\section{Hole 803D}

Among 19 samples examined from Core 130-803D-68R, only 3 samples yielded identifiable, but poorly preserved radiolarians (Table 1 and Fig. 2). They are found in Section 130-803D-68R-3 at intervals of $86-87,89-90$, and $96-98 \mathrm{~cm}$. The sediments containing preserved radiolarians are within dark yellowish brown (10YR 4/4) radiolarites.
Sample 130-803D-68R-3, 89-90 cm, yielded the best preserved and most abundant radiolarians among the samples examined in this study. The key species observed in this sample are Pseudodictyomitra pseudomacrocephala $(\mathrm{A}=$ abundant $)$, Thanarla elegantissima $(\mathrm{C}=$ common) $T$. veneta (A), and $T$. praeveneta (A). A sample below (130-803D-68R-3, 96-98 cm) yielded fewer radiolarians of poor preservation, consisting of Pseudodictyomitra pseudomacrocephala $(\mathrm{F}=$ few $), T$. elegantissima $(\mathrm{R}=\mathrm{rare})$, and $T$. praeveneta $(\mathrm{C})$, but without $T$. veneta. On the other hand, a sample above (130-803D-68R$3,86-87 \mathrm{~cm}$ ) contained $P$. pseudomacrocephala $(\mathrm{F})$ together with both Thanarla praeveneta $(\mathrm{F})$ and $T$. veneta $(\mathrm{F})$. Thus, the age of at least the two younger samples, and possibly the remaining older one, can be assigned to the Thanarla veneta Zone (95-97 Ma: Schaaf, 1985; Thurow, 1988) of the late late Albian or the upper part of the Acaeniotyle umbilicata Zone (Foreman, 1975; Sanfilippo and Riedel, 1985).

\section{Hole 807C}

Radiolarian abundance increased with a drastic change in lithology from limestone to brown siltstone from Cores $130-807 \mathrm{C}-71 \mathrm{R}$ to 
Table 1. Stratigraphic distribution and abundances of Cretaceous radiolarians from Holes 803D and 807C.

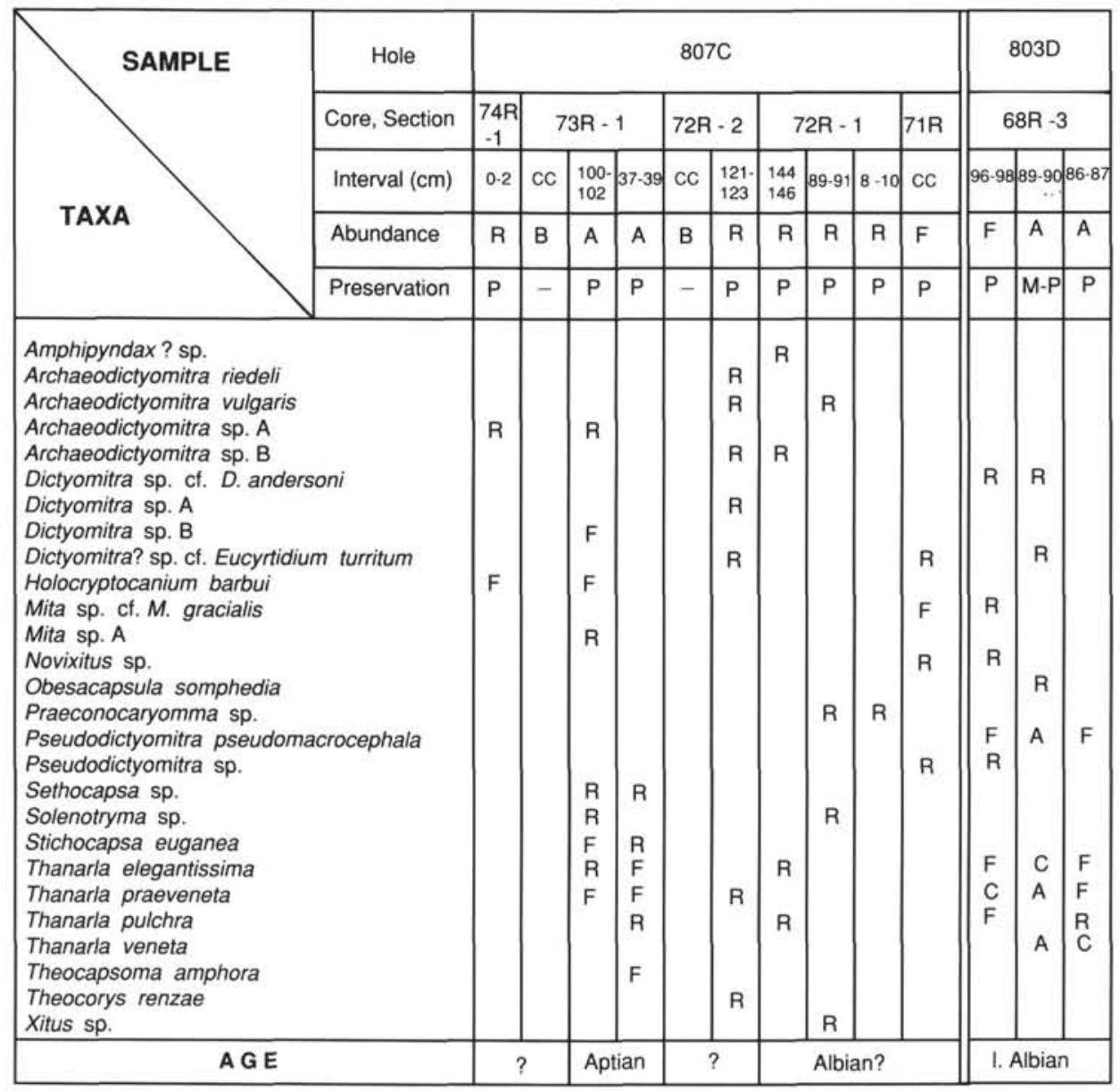

Notes: The following criteria are used to determine radiolarian species abundances: abundant $(A)=>50$ specimens observed; common $(C)=26-50$ specimens; few $(F)=6-25$ specimens; rare $(R)=\leq 5$ specimens; and barren $(B)=$ absent. Abundances of the assemblages are given as a mean of species abundance.

$-73 R$. All specimens were poorly preserved as a result of diagenesis and/or being filled with quartz or zeolite similar to the preservation status of the samples from Hole 803D.

In sharp contrast to Hole $803 \mathrm{D}$, the radiolarians are generally less abundant, and no single taxon dominates the assemblages. Two samples (130-807C-73R-1, 37-39 cm, and -73R-1, 100-102 cm; Table 1 and Fig. 2), are considered to be stratigraphically the most significant for Cretaceous radiolarian fauna recovered during Leg 130. They are unambiguously assigned to the early Aptian (Sanfilippo and Riedel, 1985; Schaaf, 1985; Thurow, 1988), although zonal assignment cannot be achieved. This age assignment is based on the presence of Stichocapsa euganea and Thanarla praeveneta, coupled with the absence of $T$. veneta and Pseudodictyomitra pseudomacrocephala (Table 1). The remainder of the radiolarian assemblages from Hole $807 \mathrm{C}$ show less clear age indication than the samples from Section 130-807C-73R-1. Four samples (130-807C-71R-CC through $-72 \mathrm{R}-1,144-146 \mathrm{~cm}$ ) probably belong to the Albian, but the assemblages found in them are not enough to clearly determine the ages (Table 1). In these four samples, Pseudodictyomitra pseudomacrocephala and Thanarla veneta are both absent. These two species were recorded from Hole 803D as few to abundant. Their absence might mean that the ages of these four samples are older than from Hole $803 \mathrm{D}$, although the generally poor preservation precluded determination of the effect of dissolution on the assemblages.

Basalt (not true basement rock, see below) was recovered in Core 130-807C-74R, and a thin layer of limestone occurred at the top of the core. Sample 130-807C-74R-1, 0-2 cm, contains a small number of poorly preserved radiolarians. Because only Holocryptocanium barbui and Archaeodictyomitra sp. A have been found in this sample (Table 1), its radiolarian age cannot be assigned.

Three sedimentary layers of limestone were recovered in Sections 130-807C-80R-1 and -82R-3 between pillow basalts. Sample 130$807 \mathrm{C}-80 \mathrm{R}-1,70-72 \mathrm{~cm}$, however, contains rare, poorly preserved, non-age-diagnostic spumellarians, whereas Samples 130-807C-80R$1,74-75 \mathrm{~cm}$, and $-82 \mathrm{R}-1,75-76 \mathrm{~cm}$, are barren of radiolarians. Consequently, no age can be assigned to this section.

\section{DISCUSSION}

The oldest possible radiolarian age at Site 803, late Albian, is clearly younger than that at Site 807 (early Aptian). This difference in their age may be partially explained in light of the much expanded sedimentation at Site 807 compared with Site 803 . Figure 2 illustrates that at Site 803 the only Cretaceous radiolarians are of late Albian age, and these are strictly confined within $12 \mathrm{~cm}$ of radiolarite samples from 130-803D-68R-3. On the other hand, at Site 807 the Cretaceous radiolarians are found in much thicker section, a total thickness of at least $17.7 \mathrm{~m}$, than at Site 803. Early Aptian radiolarians and possibly younger radiolarians were found in radiolarian siltstone Samples $130-807 \mathrm{C}-71 \mathrm{R}-\mathrm{CC}$ to $73 \mathrm{R}-1,100-102 \mathrm{~cm}$. Beneath the radiolarian siltstones, a layer of limestone was found directly above pillow basaltic flows (Sample 130-807C-74R-1, 0-2 cm), as discussed ear- 


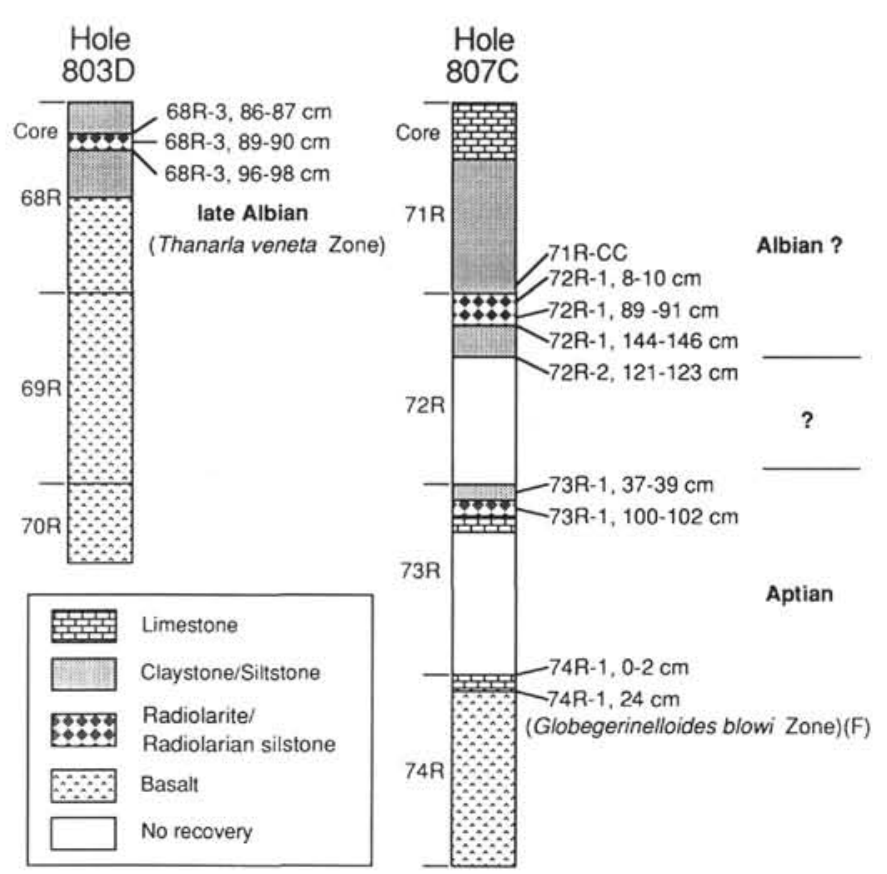

Figure 2. Simplified lithology, radiolarian age, and sample positions of the Cretaceous sections examined in Holes 803D and 807C. Only the samples containing radiolarians are shown. Planktonic foraminifer ages (Tarduno et al., 1991) are also shown as a reference. $\mathrm{F}=$ planktonic foraminiferal zone.

lier. It contains only two taxa of no age significance. However, the planktonic foraminifer age of the Globigerinelloides blowi Zone has been already determined from $22 \mathrm{~cm}$ below this sample within the same limestone layer (Fig. 2) (Tarduno et al., 1991). Furthermore, paleomagnetic analysis of the basalts at Site 807 suggests that much of the Ontong Java Plateau was formed during the early Aptian. Thus, the sequence of sedimentary layers stretching $8.62 \mathrm{~m}$ from directly above the basaltic flows to Sample 130-807C-73R-1, 37-39 cm, all belong to the Aptian.

It is clear that sediment preserved at Site 803 is more greatly reduced than at Site 807 . Therefore, a large-scale hiatus is considered to have occurred below the radiolarites at Site 803 (see also Kroenke, Berger, Janecek, et al., 1991). If the sedimentation at Site 807 is simply an expanded version of Site 803 , however, then we should encounter similar late Albian radiolarian assemblages (i.e., $T$. veneta Zone) at Site 807 as well. The fact that assemblages of Samples 130-807C-71R-CC through -72R-2, 144-146 cm, and those at Site 803 are different, the former possibly being slightly older than the latter, suggests that the sedimentation processes at the two sites were different. The question of why the radiolarian assemblage of the $T$. veneta Zone was not found at Site 807 cannot be answered at this time. It can be postulated, however, that the seemingly different ages of late Albian (Site 803) and Albian? (Site 807) are because the sediments were deposited at different times.

The radiolarian ages derived from this study are conformable with those of previous works. Tarduno et al. (1991) discussed the timing of flood-basalt volcanism with the formation of the Ontong Java Plateau and summarized the available biostratigraphic and paleomagnetic information to date from the area. Results from previous DSDP sites provide evidence for widespread volcanism occurring about the same time (Tarduno et al., 1991; see also Table 2). Based on this information, Tarduno et al. (1991) concluded that the Ontong Java volcanic event occurred during the early Aptian and that the event may have been the largest during the past $200 \mathrm{~m} . y$. Furthermore, they suggest that the rate of the early Aptian volcanism $\left(8-22 \mathrm{~km}^{3} / \mathrm{year}\right)$ is more than several times greater than rates calculated for continental flood basalts such as the Deccan Traps. The biostratigraphic information provided by this study, a part of which (Site 807) is in accord with the list of the age information on the "mid-Cretaceous" volcanism, is significant to the history of our own planet.

North of the Ontong Java Plateau lies the East Mariana Basin, the site of ODP Leg 129. Cretaceous radiolarians were also encountered from sediments proximal to basalt, and the oldest radiolarian ages recognized from lowermost Sample 129-802A-56R-2, 57-61 cm, were the upper Acaeniotyle umbilicata to lower Obesacapsula somphedia zones of the late Albian to Cenomanian (Lancelot, Larson, et al., 1990). In samples below this radiolarian-bearing horizon, some calcareous nannofossils and palynoflora were present. They suggest a possible age of late Aptian or younger (Lancelot, Larson, et al., 1990; A. Matsuoka, pers. comm., 1991).

Finally, an absolute age assignment for Cretaceous radiolarian zones is difficult. This is because no recent compilations exist with references to co-occurring microfossils (Sanfilippo and Riedel, 1985; A. Sanfilippo, pers. comm., 1992). Different radiolarian papers use different time scales. It is hoped that our knowledge of Cretaceous chronostratigraphy will advance based on future Cretaceous biostratigraphic studies that will correlate radiolarians with other microfossil groups such as planktonic foraminifers as well as with the paleomagnetic record.

\section{CONCLUSION}

The radiolarian ages derived from Cretaceous sediments found at Sites 803 and 807 are the late Albian and early Aptian, respectively. Considering the greatly reduced sediment thickness of Site 803 compared with Site 807 , the oldest radiolarian-bearing sediments found at Site 807 can be considered to represent successive timing of the end of flood volcanism in the region. Thus, the present results support the contention that the timing of the termination of large-scale flood basalt volcanism, responsible for the formation of the Ontong Java Plateau, was the early Aptian. The fact that the Albian radiolarian fauna found at Site 803 were not repeated at Site 807 suggests that the Cretaceous sediments recovered at the two sites were deposited at different times. A large-scale hiatus below the late Albian radiolarite at Site 803 is considered.

\section{ACKNOWLEDGMENTS}

We acknowledge financial support by ODP/NSF in enabling the senior author to participate in the Leg 130 cruise and carrying out the post-cruise study, and NIU Presidential Research Professorship for the junior author to undertake the analysis. This paper has been improved by the critical comments provided by Drs. W.A. Berggren, R.D. Norris, A. Sanfilippo, and J. Thurow; we gratefully thank their effort in reviewing the manuscript. We benefited from a discussion with Dr. A. Matsuoka on Leg 129 Cretaceous and Jurassic biostratigraphy in the western Pacific. This is Woods Hole Oceanographic Institution Contribution No. 7960.

\section{REFERENCES}

Andrews, J.E., Packham, G., et al., 1975. Init. Repts. DSDP, 30: Washington (U.S. Govt. Printing Office).

Baumgartner, P.O., 1984. A Middle Jurassic-Early Cretaceous low-latitude radiolarian zonation based on unitary association and age of Tethyan radiolarites. Eclogae Geol. Helv., 77:729-837.

Campbell, A.S., and Clark, B.L., 1944. Radiolaria from Upper Cretaceous of middle California. Spec. Pap., Geol. Soc. Am., 57:1-61.

Cita, M.B., 1964. Ricerche micropaleontologiche e stratigrafiche sui sedimenti pelagiche del Giurassico superiore e del Cretaceo inferiore nella catena del Monte Baldo. Mem. Riv. Ital. Paleontol. Stratigr., 10:1-182.

Dumitrica, P., 1970. Cryptocephalic and cryptothoracic Nassellaria in some Mesozoic deposits of Roumania. Rev. Roum. Geol. Geophys. Geogr., Ser Geol., 14:45-124. 
Foreman, H.F., 1968. Upper Maestrichtian Radiolaria of California. Paleontol. Assoc. London, 3:1-82.

1973. Radiolaria from DSDP Leg 20. In Heezen, B.C., MacGregor, I.D., et al., Init. Repts. DSDP, 20: Washington (U.S. Govt. Printing Office), 249-305.

, 1975. Radiolaria from the North Pacific, Deep Sea Drilling Project, Leg 32. In Larson, R.L., Moberly, R., et al., Init. Repts. DSDP, 32: Washington (U.S. Govt. Printing Office), 579-676.

Hinde, G.J., 1902. Description of fossil Radiolaria from the rocks of central Borneo. In Molengraaff, G.A.F. (Ed.), Borneo-Expeditie: Geologische Verkenningstochten in Central Borneo (1893-1894): Leiden (E.J. Brill), $1-51,54-56$.

Kroenke, L.W., Berger, W.H., Janecek, T.R., et al. 1991. Proc. ODP, Init. Repts., 130: College Station, TX (Ocean Drilling Program).

Lancelot, Y., Larson, R.L., et al., 1990. Proc. ODP, Init. Repts., 129: College Station, TX (Ocean Drilling Program).

Ling, H.-Y., 1973. Radiolaria: Leg 19 of the Deep Sea Drilling Project. In Creager, J.S., Scholl, D.W., et al., Init. Repts. DSDP, 19: Washington (U.S. Govt. Printing Office), 777-797.

Moore, T.C., Jr., 1973. Radiolaria from Leg 17 of the Deep Sea Drilling Project. In Winterer, E.L., Ewing, J.I., et al., Init. Repts. DSDP, 17: Washington (U.S. Govt. Printing Office), 797-869.

Parona, C.F., 1890. Radiolarie nei noduli selciosi del calcare giurese di Cittiglio presso Laveno. Boll. Soc. Geol. Ital., 9:132-175.

Pessagno, E.A., Jr., 1977. Lower Cretaceous radiolarian biostratigraphy of the Great Valley sequence and Franciscan complex, California coast ranges. Spec. Publ., Cushman Found. Foraminiferal Res., 15:1-87.

Renz, G.W., 1974. Radiolaria from Leg 27 of the Deep Sea Drilling Project. In Veevers, J.J., Heirtzler, J.R., et al., Init. Repts. DSDP, 27: Washington (U.S. Govt. Printing Office), 769-841.

Riedel, W.R., and Sanfilippo, A., 1971. Cenozoic Radiolaria from the western tropical Pacific. In Winterer, E.L., Riedel, W.R., et al., Init. Repts. DSDP, 7: Washington (U.S. Govt. Printing Office), 1529-1672.

Sanfilippo, A., and Riedel, W.R., 1985. Cretaceous radiolaria. In Bolli, H.M., Saunders, J.B., Perch-Nielsen, K. (Eds.), Plankton Stratigraphy: Cambridge (Cambridge Univ. Press), 573-630.

Schaaf, A., 1981. Late Early Cretaceous Radiolaria from Deep Sea Drilling Project Leg 62. In Thiede, J., Vallier, T.L., et al., Init. Repts. DSDP, 62: Washington (U.S. Govt. Printing Office), 419-470.

, 1984. Les Radiolaires du Crétacé Inférieur et Moyen: biologie et systématique. Univ. Louis Pasteur, Strasbourg Inst. Geol., Sci. Geol. Mem., 75:1-189.

1985. Un nouveau canevas biochronologique du Crétacé inférieur et moyen: les biozones a radiolaires. Univ. Louis Pasteur, Strasbourg Inst. Geol., Sci. Geol. Bull., 38:227-269.

Shipboard Scientific Party, 1986. Site 586. In Moberly, R., Schlanger, S.O., et al., Init. Repts. DSDP, 89: Washington (U.S. Govt. Printing Office), 213-235.

Squinabol, S., 1903. Le radiolarie dei Noduli selciosi nella scaglia degli Euganei. Riv. Ital. Paleontol., 9:105-150.

, 1904. Radiolarie Cretacee degli Euganei. Atti. Mem., Accad. Sci. Let. Art., Padova, Nov. Ser., 20:172-244.

Taketani, Y., 1982. Cretaceous radiolarian biostratigraphy of the Urakawa and Obira areas, Hokkaido. Sci. Repts. Tohoku Univ., Ser. 2, 52:1-76.

Tan Sin Hok, 1927. Over de samenstelling en het onstaan van krijt-en mergelgesteenten van de Molukken. Jaarb. Mijnwezen Nederl. Oost-Indie, Jaarg. 55 (1926), Verh., 5-165.

Tarduno, J.A., Sliter, W.V., Kroenke, L., Leckie, M., Mayer, H., Mahoney, J.J., Musgrave, R., Storey, M., and Winterer, E.L., 1991. Rapid formation of Ontong Java Plateau by Aptian mantle plume volcanism. Science, 254:399-403.

Thurow, J., 1988. Cretaceous radiolarians of the North Atlantic Ocean: ODP Leg 103 (Sites 638, 640, and 641) and DSDP Legs 93 (Site 603) and 47B (Site 398). In Boillot, G., Winterer, E.L., et al., Proc. ODP, Sci. Results, 103: College Station, TX (Ocean Drilling Program), 379-418.

Date of initial receipt: 19 December 1991

Date of acceptance: 17 May 1992

Ms 130B-019

\section{TAXONOMIC NOTES}

Because of the generally poor preservation, it is difficult, if not impossible, to identify many radiolarians satisfactorily, especially long, multi-segmented forms. Radiolarian taxa recognized in samples from Holes $803 \mathrm{D}$ and $807 \mathrm{C}$ are listed in alphabetical order. As most of taxa have been critically treated recently (Schaaf, 1981, 1984; Sanfilippo and Riedel, 1985; Thurow, 1988), beside the original and the latest references, additional remarks based on the present study are given whenever it is deemed appropriate. Location of the illustrated specimens by transmitted light microscopy is given in the following manner: cruise-hole-core-section, sample interval, slide number, and finally England Finder coordinates (Ling, 1973) in parenthesis.

Amphipyndax sp. (Plate 2, Fig. 1)

Archaeodictyomitra riedeli Taketani (Plate 2, Fig. 2)

Archaeodictyomitra riedeli Taketani, 1982, pp. 57-58, pl. 4, figs. 4a-b; pl. 12, fig. 1.

Archaeodictyomitra vulgaris Pessagno (Plate 2, Fig. 3; Plate 3, Fig. 3)

Archaeodictyomitra vulgaris Pessagno, 1977, p. 44, pl. 6, fig. 15; Schaaf, 1981, p. 432, pl. 4, fig. 2; Thurow, 1988, p. 398, pl. 6, fig. 19.

Archaeodictyomitra sp. A (Plate 2, Fig. 4)

Archaeodictyomitra sp. B (Plate 2, Fig. 5)

Dictyomitra sp. cf. D. andersoni (Campbell and Clark) (Plate 2, Figs. 6 and 7; Plate 3, Fig. 4)

Dictyomitra sp. cf. D. andersoni (Campbell and Clark), Moore, 1973, p. 829 , pl. 9 , fig. 5 .

Remarks: The species is similar to those illustrated by Moore from the low-latitude northeastern Pacific.

Dictyomitra sp. A (Plate 2, Fig. 8)

Remarks: This elongated form resembles those reported as $D$. sp. $A$ by Taketani (1982, p. 59, pl. 4, figs. 7a-b) from Japan.

\section{Dictyomitra sp. B (Plate 2, Fig 9)}

Remarks: Although longitudinal costae were not apparent, the specimens are provisionally assigned to the present genus based on the general similarity with those of $D$. urakawensis (Taketani, 1982, p. 59, pl. 4, figs. 8a-b; pl. 11, fig. 16), especially in the shapes of segments and deep strictures between adjoining postabdominal segments.

Dictyomitra? sp. cf. Eucyrtidium turritum Moore (Plate 3, Fig. 5)

Dictyomitra? sp. cf. Eucyrtidium turritum Moore (non Squinabol), 1973, p. 830 , pl. 10 , figs. 4 and 5 (only)

Remarks: The present form is considered as conspecific with Moore's specimens from the low-latitude northeastern Pacific. Although Moore (1973) compared the present taxon with that of Squinabol's (1904, p. 234, pl. 10, fig. 9), the illustrated Italian specimen shows definite longitudinal costae, and a gradual increase of width in the postabdominal segments, whereas both Pacific forms show very little increase in their width, thus showing a slender outline.

Holocryptocanium barbui Dumitrica, 1970 (Plate 3, Fig. 1)

Holocryptocanium barbui Dumitrica, 1970, pl. 17, figs. 105 to 108a-b; pl. 21, fig. 136.

Mita sp. cf. M. gracilis Thurow (Plate 3, Fig. 6)

Mita gracilis Thurow (not Squinabol), 1988, p. 402, pl. 3, fig. 2.

Remarks: Leg 130 specimens display a more inflated cephalo-thoracic segment than those illustrated by Thurow (1988) from the North Atlantic. It should be added here that Thurow considered his specimens as conspecific with Sethoconus gracilis Squinabol (1903, p. 131, pl. 10, fig. 13) and Mita gracilis (Squinabol) by Taketani (1982, p. 60, pl. 5, figs. 2a-b; pl. 12, fig. 3; Schaaf, 1984, pp. 110-111, text figs. 5a-c). However, the original Squinabol, and subsequent Taketani and Schaaf specimens clearly refer to the conical form without any inflation of the cephalo-horacic segment, thus showing a continuous smooth outline.

Mita sp. A (Plate 2, Fig. 11) 
Mita sp. A, Thurow, 1988, p. 402, pl. 3, fig. 1.

Remarks: The species agrees well with North Atlantic forms described by Thurow (1988), especially in its rounded apical area and oval outline in lateral view. Thurow considered the species to be probably related to Pessagno's $M$. sp. B (1977, p. 45, pl. 7, fig. 6), but the latter shows more narrow and pointed apical areas and therefore a more slender outline overall.

Novixitus sp. (Plate 2, Fig. 12; Plate 3, Fig. 7)

Remarks: Although the detailed surface ornamentation was obscure enough to prevent us from identifying the present taxon to a specific level, the presence of circumferentially arranged rows of very large tubercles are apparent enough to place the specimen in this genus.

Obesacapsula somphedia (Foreman) (Plate 3, Fig. 8)

Dictyomitra somphedia Foreman, 1973, p. 264, pl. 14, fig. 18; Foreman, 1975 , p. 614 , pl. 7 , figs. 11-13.

Obesacapsula somphedia (Foreman), Schaaf, 1981, p. 435, pl. 4, figs. 6-9; pl. 20, figs. 1a-b, 2 .

Praeconocaryomma sp. (Plate 1, Figs. 1-2; Plate 3, Fig. 2)

Pseudodictyomitra pseudomacrocephala (Squinabol) (Plate 2, Figs. 13-14; Plate 3, Fig. 9)

Dictyomitra pseudomacrocephala Squinabol, 1903, p. 139, pl. 10, fig. 2.

Pseudodictyomitra pseudomacrocephala (Squinabol), Thurow, 1988, p. 405, pl. 1, fig. 13; pl. 3, fig. 16.

Pseudodictyomitra sp. (Plate 2, Fig. 10; Plate 3, Fig. 10)

Sethocapsa sp. (Plate 1, Figs. 6-7)

Remarks: The small, conical, proximal part and a spineless, large, globose distal segment characterize the present species. Constrictions are indicated that suggest the presence of multi-segments but they cannot be confirmed.

Some of the Late Early Cretaceous specimens illustrated by Foreman (1975, p. 617, pl. 2I, figs. 11, 12, and 14) from the Northwest Pacific are probably conspecific and within the similar size range.

Solenotryma sp. (Plate 1, Fig. 4)

Solenotryma sp. Schaaf, 1981, p. 438, pl. 23, figs. 4a-b.

Remarks: This species is provisionally assigned here to indicate a close similarity with those from the North Pacific illustrated by Schaaf (1988). Structurally, this species resembles S. japonica Taketani (1982, p. 68, pl. 7, figs. $9 \mathrm{a}-\mathrm{b}$ and $10 \mathrm{a}-\mathrm{b} ; \mathrm{pl}$. 13, figs. 16-17) but without the longitudinal costae in the third segment.

Stichocapsa euganea Squinabol (Plate 1, Fig. 5)

Stichocapsa euganea Squinabol, 1903, pp, 142-143, pl. 8, fig. 30.

Archicapsa similis Schaaf (non Parona), 1981, p. 432, pl. 22, figs. 4-5; pl. 23, fig. 7.

Remarks: Specimens observed during the present study agree well with the original illustration of Squinabol (1903) in their smooth outline, although they are only about one-half the size.

Schaaf (1981) regarded his central North Pacific specimens as synonymous with those of Parona's Archicapsa similis (1890, p. 163, pl. 5, fig. 4).
However, according to Hinde (1902, pl. 3, fig. 22) and Moore (1973, p. 825, pl. 16, figs. 3-4), the last segment is a sharply increased sphere that displays a discontinuous outline. Therefore, it is considered here that these latter forms are different from Schaaf's.

Thanarla elegantissima (Cita) (Plate 1, Fig. 9; Plate 3, Fig. 11)

Lithocampe elegantissima Cita, 1964, p. 148, pl. 12, figs. 2-3.

Thanarla elegantissima (Cita), Pessagno, 1977, p. 46, pl. 7, fig. 10; Thurow, 1988 , p. 407 , pl. 4, fig. 11, see also for synonymy.

Remarks: The species is characterized by a nearly straight abdominal outline.

Thanarla praeveneta Pessagno (Plate 1, Figs. 11, 12; Plate 3, Figs. 13-15)

Thanarla praeveneta Pessagno, 1977, p. 46, pl. 7, figs. 11, 16, 18, 23, and 27.

Remarks: A less pronounced proximal lobe than originally described by Pessagno (1977) characterizes the species. Judging from the faunal composition, we also agree that the present species gave rise to $T$. veneta.

Thanarla pulchra (Squinabol) (Plate 1, Fig. 10; Plate 3, Fig. 12)

Sethamphora pulchra Squinabol, 1904, p. 213, pl. 5, fig. 8.

Thanarla pulchra (Squinabol), Pessagno, 1977, p. 46, pl. 7, figs. 7, 21, and 26; Thurow, 1988, p. 407, pl. 7, fig. 9.

Thanarla veneta (Squinabol) (Plate 1, Fig. 13; Plate 3, Fig. 16)

Phormocyrtis veneta Squinabol, 1903, p. 134, pl. 9, fig. 30.

Thanarla veneta (Squinabol), Pessagno, 1977, p. 46, pl. 7, figs. 5 and 12; Thurow, 1988, p. 407, pl. 4, figs. 13-14.

Remarks: The initial geological occurrence of the present taxon was reported as Cenomanian by Pessagno (1977), but as late Albian by Thurow (1988).

Theocapsomma amphora Campbell and Clark, emend. Foreman (Plate 1, Fig. 3)

Theocapsa (Theocapsomma) amphora Campbell and Clark, 1944, p. 35, pl. 7, figs. 30-31; Foreman, 1968, p. 31, pl. 4, figs. 9a-c.

Tricolocapsa (Tricolocapsium) granti Campbell and Clark, 1944, p. 35, pl. 7, figs. 37-38.

Remarks: Specimens assigned as ?Tricolocapsa parvipora Tan by Renz (1974, p. 798, pl. 6, figs. 8-12) seem closely related to the present species. However, Tan's original species (1927, p. 48, pl. 9, figs. 59-60) possess a much-reduced thoracic segment and thus display an oval outline.

Theocorys renzae Schaaf (Plate 1, Fig. 8)

Theocorys renzae Schaaf, 1981, p. 440, pl. 5, figs. 13a-c; pl. 27, figs. 1a-b.

Remarks: A four-segmented nature cannot be confirmed from the recovered specimens, and the specimen illustrated here is slightly smaller in total length than those originally reported from the North Pacific (Schaaf, 1981). However, the specimens are assigned to this species based on the overall appearance, particularly in that the surface pores are not aligned in longitudinal rows and a constricted aperture is present, as illustrated by Schaaf (1981, pl. 5, figs. 13a-c).

Xitus sp. (Plate 2, Fig. 15) 
Table 2. Summary of known chronostratigraphic information on oldest age sediments corresponding to formation of the Ontong Java Plateau and its basalt.

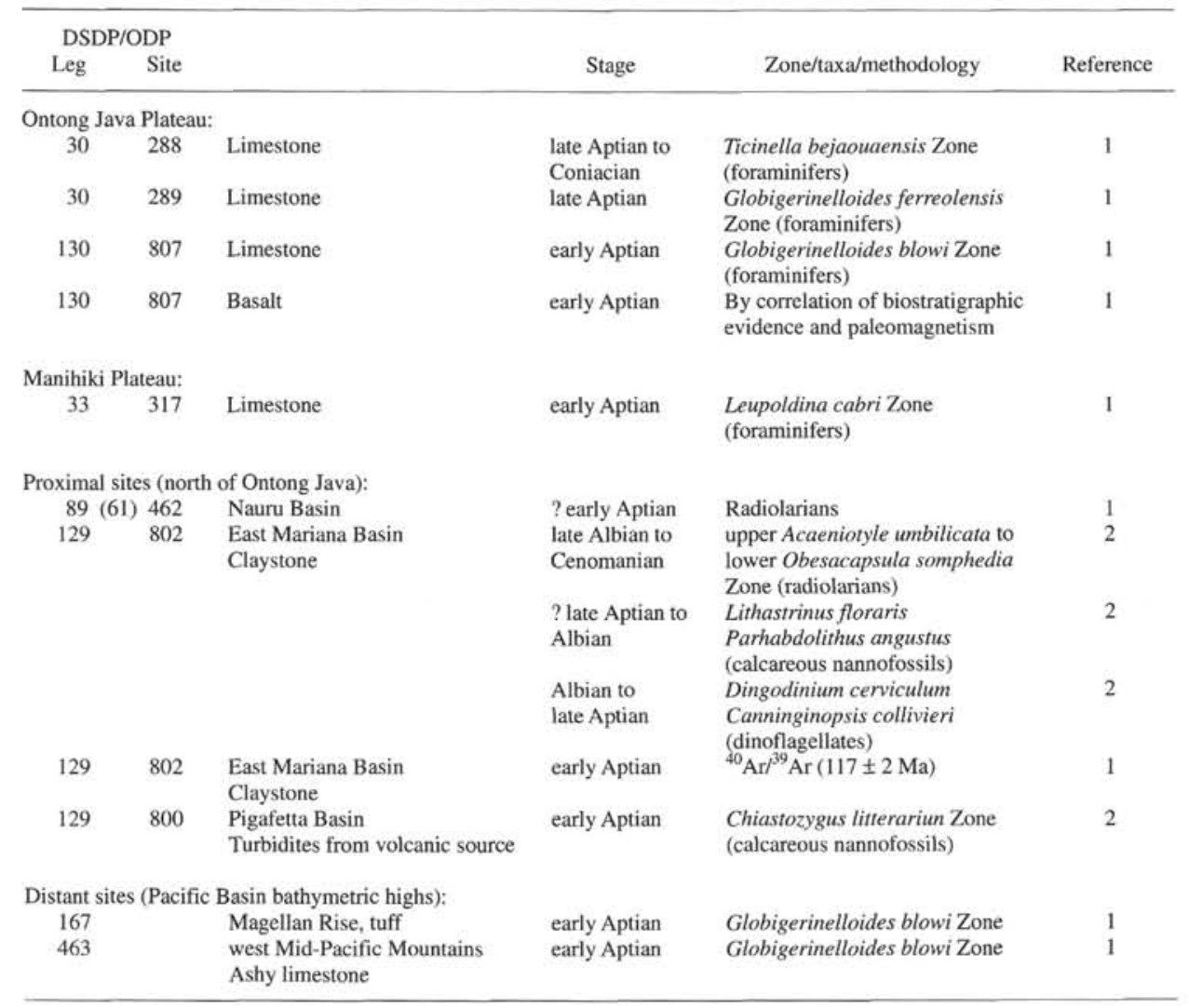

Note: References are as follows: $1=$ Tarduno et al. (1991) and 2 = Lancelot, Larson, et al. (1990). 


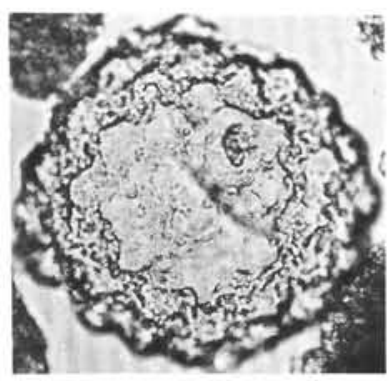

1

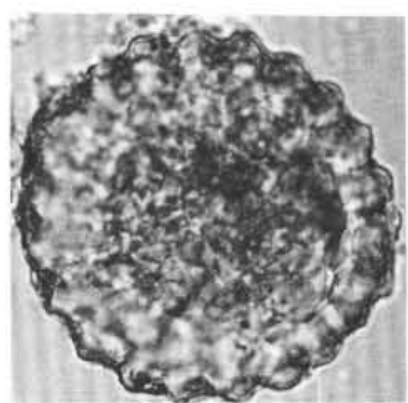

2

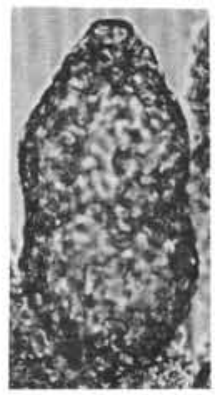

3

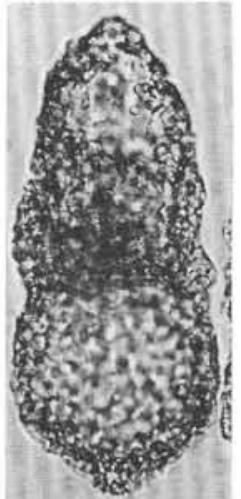

4

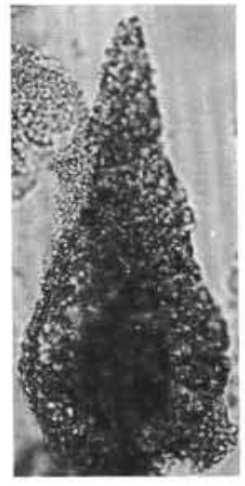

5

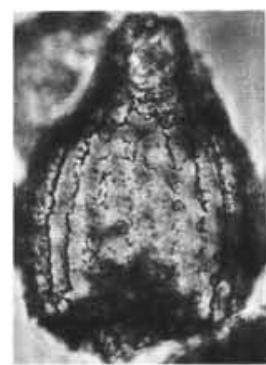

9

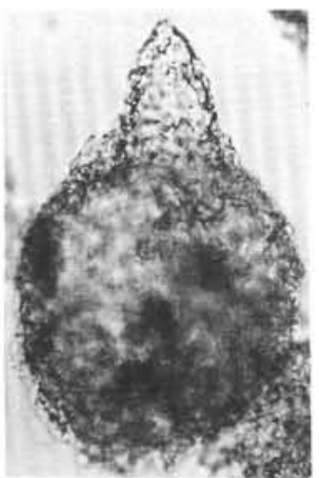

6

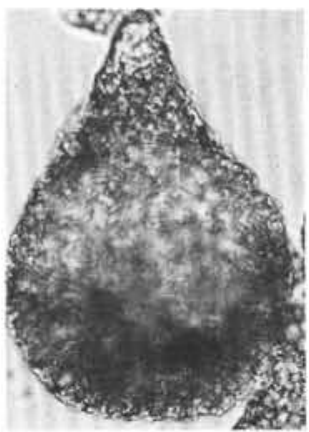

7

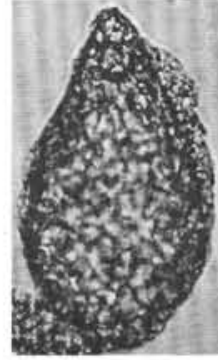

8

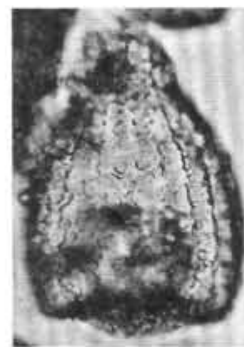

10

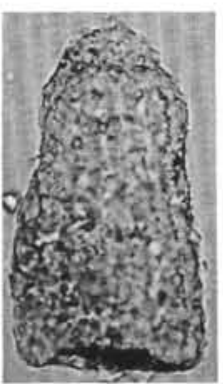

11

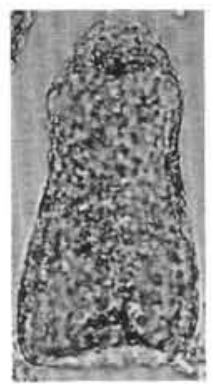

12

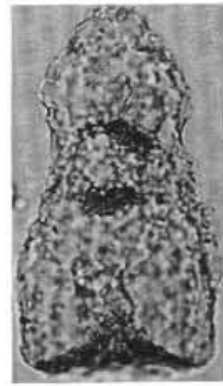

13

Plate 1. Magnification $\times 200$ unless otherwise indicated. 1. Praeconocaryomma sp., Sample 130-807C-72R-1, 89-91 cm, R-3(N38/4). 2. Praeconocaryomma sp., Sample 130-803D-68R-3, 89-91 cm, R-1 (T50/3), ×250. 3. Theocapsomma amphora, Sample 130-807C-73R-1, 37-39 cm, R-1 (H39/4), $\times 250$. 4. Solenotryma sp., Sample 130-807C-72R-1, 89-91 cm, R-1 (N11/1), $\times 250$. 5. Stichocapsa euganea, Sample 130-807C-73R-1, 37-39 cm, R-1 (U5/2). 6. Sethocapsa sp., Sample 130-807C-73R-1, 100-102 cm, R-1 (U31/4). 7. Sethocapsa sp., Sample 130-807C-73R-1, 37-39 cm, R-1 (V11/0). 8. Theocorys renzae, Sample 130-807C-72R-2, 121-123 cm, R-1 (F26/2), $\times 250$. 9. Thanarla elegantissima, Sample 130-807C-72R-1, 144-146 cm, R-1 (011/1). 10. Thanarla pulchra, Sample 130-807C-73R-1, 100-102 cm, R-1 (U32/1). 11. Thanarla praeveneta, Sample 130-803D-68R-3, 89-90 cm, R-2 (N15/2). 12. Thanarla praeveneta, Sample 130-803D-68R-3, 89-90 cm, R-1 (T45/2). 13. Thanarla veneta, Sample 130-803D-68R-3, 89-90 cm, R-1 (Y37/1). 


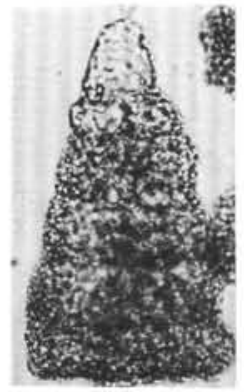

1

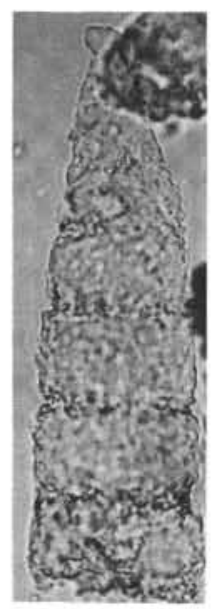

6

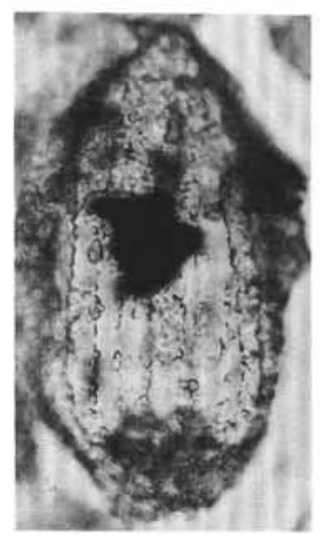

11

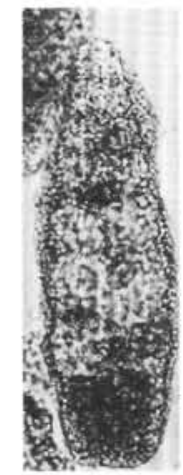

2

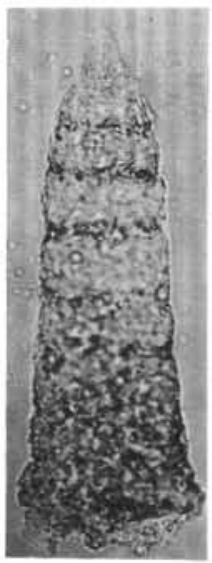

7

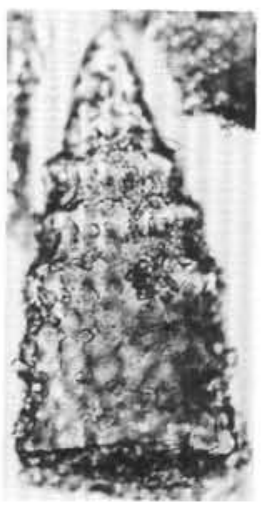

12

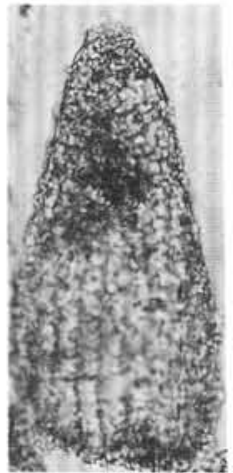

3

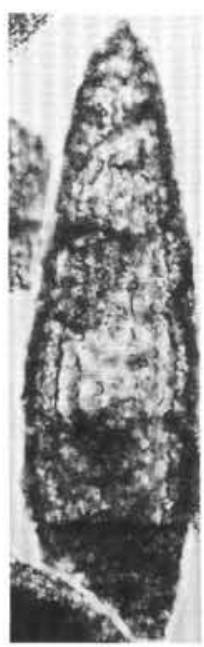

8

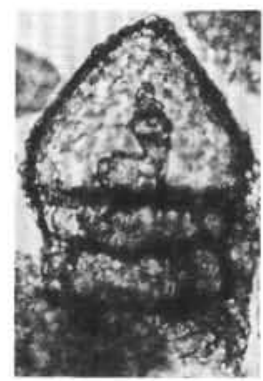

13

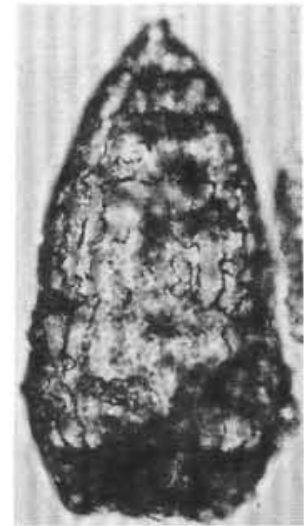

4

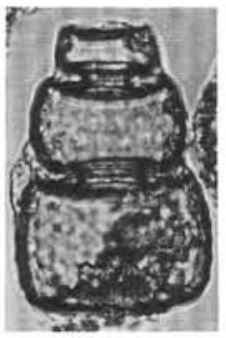

9

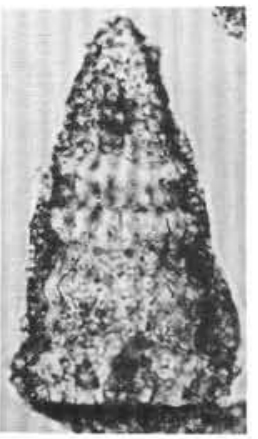

10

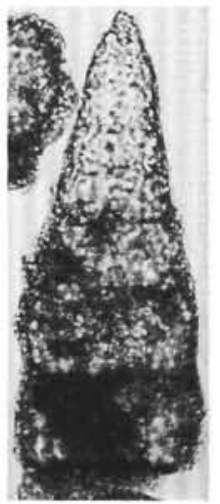

15

Plate 2. Magnification $\times 200$ unless otherwise indicated. 1. Amphipyndax sp., Sample 130-807C-72R-1, 144-146 cm, R-2 (T34/2). 2. Archaeodictyomitra riedeli, Sample 130-807C-72R-2, 121-23 cm, R-1 (S32/4), $\times 160$. 3. Archaeodictyomitra vulgaris, Sample 130-807C-72R-1, 89-91 cm, R-1 (W6/0). 4. Archaeodictyomitra sp. A, Sample 130-807C-73R-1, 100-102 cm (053/4). 5. Archaeodictyomitra sp. B, Sample 130-807C-72R-1, 144-146 cm, R-2 (N41/4). 6. Dictyomitra? sp. cf. D. andersoni, Sample 130-803D-68R-3, 89-90 cm, R-1 (F25/0). 7. Dictyomitra? sp. cf. D. andersoni, Sample 130-803D-68R-3, 96-98 cm, R-2 (J25/2), ×160. 8. Dictyomitra sp. A, Sample 130-807C-72R-2, 121-123 cm, R-1 (U48/0). 9. Dictyomitra sp. B, Sample 130-807C-73R-1, 100-102 $\mathrm{cm}, \mathrm{R}-1$ (E36/3), $\times 250$. 10. Pseudodictyomitra sp., Sample 130-807C-71R-CC, R-1 (K7/4), $\times 160$. 11. Mita sp. A, Sample 130-807C-73R-1, 100-102 cm, R-1 (Y2813). 12. Novixitas sp., Sample 130-807C-71R-CC, R-1 (R29/3), $\times 160$. 13. Pseudodictyomitra pseudomacrocephala, Sample 130-803D-68R-2, 89-90 $\mathrm{cm}, \mathrm{R}-1$ (R48/1). 14. Pseudodictyomitra pseudomacrocephala, Sample $130-803 \mathrm{D}-68 \mathrm{R}-3,89-90 \mathrm{~cm}, \mathrm{R}-1$ (Q32/0), $\times 160$. 15. Xitus sp., Sample 130-807C-72R1, 89-91 cm, R-1 (W19/0), ×160. 


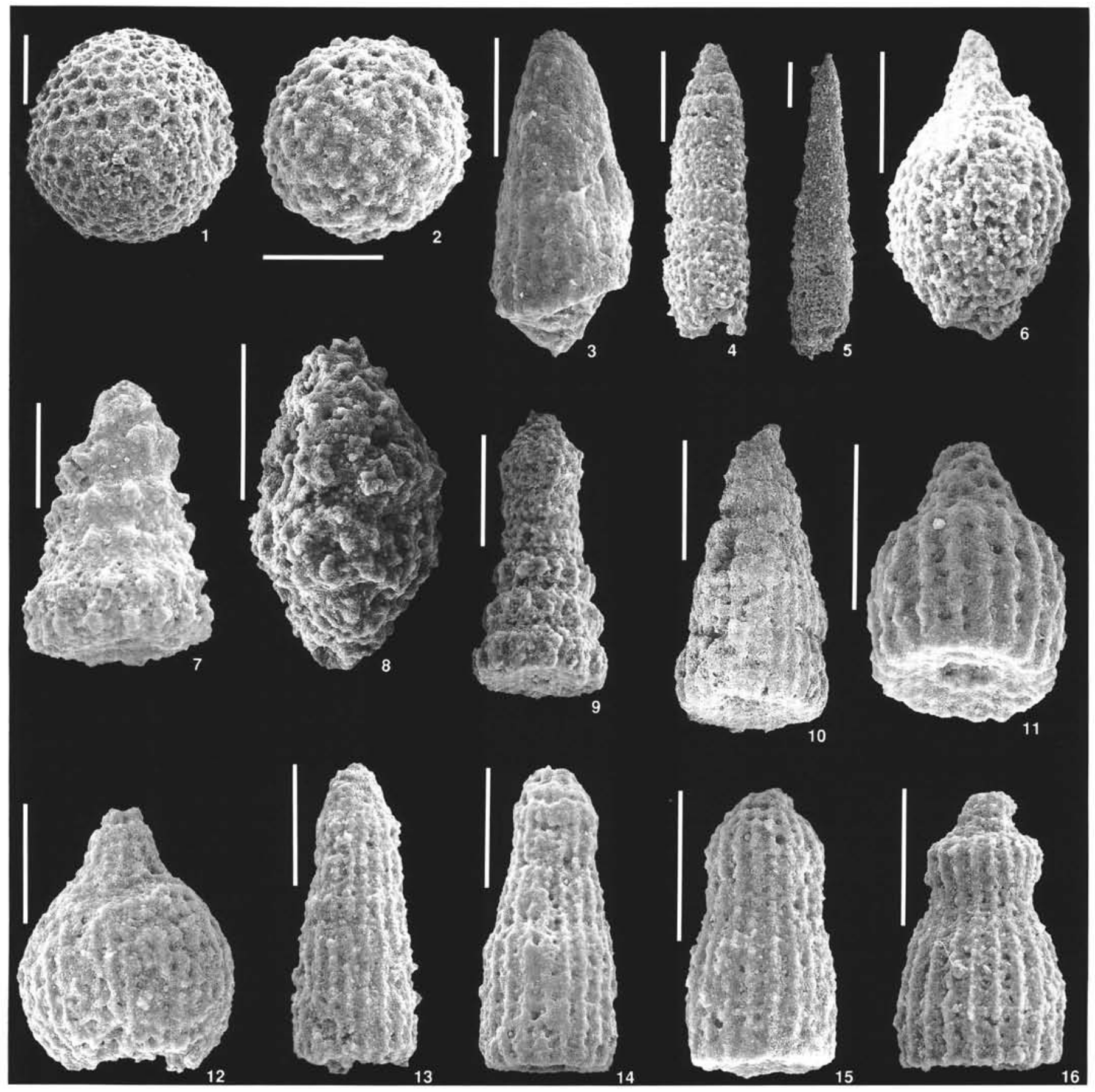

Plate 3. Scale bar $=100 \mu \mathrm{m}$. 1. Holocryptocanium barbui, Sample 130-803D-68R-3,96-98 cm. 2. Praeconocaryomma sp., Sample 130-803D-68R-3, 96-98 cm. 3. Archaeodictyomitra vulgaris, Sample 130-807C-72R-2, 121-123 cm. 4. Dictyomitra sp. cf. D. andersoni, Sample 130-803D-68R-3, 96-98 cm. 5. Dictyomitra? sp. cf. Eucyrtidium turritum, Sample 130-807C-72R-2, 121-123 cm. 6. Mita sp. cf. M. gracilis, Sample 130-803D-68R-3, 96-98 cm. 7. Novixitus sp. Sample 130-803D-68R-3,96-98 cm. 8. Obesacapsula somphedia, Sample 130-803D-68R-3,96-98 cm. 9. Pseudolofictyomitra pseudomacrocephala, Sample 130-803D-68R-3, 96-98 cm. 10. Pseudodictyomitra sp., Sample 130-803D-68R-3, 96-98 cm. 11. Thanarla elegantissima, Sample 130803D-68R-3, 96-98 cm. 12. Thanarla pulchra, Sample 130-803D-68R-3, 96-98 cm. 13. Thanarla praeveneta, Sample 130-803D-68R-3, 96-98 cm. 14. Thanarla praeveneta, Sample $130-803 \mathrm{D}-68 \mathrm{R}-3,96-98 \mathrm{~cm}$. 15. Thanarla praeveneta, Sample $130-803 \mathrm{D}-68 \mathrm{R}-3,96-98 \mathrm{~cm}$. 16. Thanarla veneta, Sample 130-803D-68R-3, 96-98 cm. 